\title{
Anti-NMDAR encephalitis with concomitant varicella zoster virus detection and nonteratomatous malignancy
}

Preeti A. Prakash, BA, * Jingxiao Jin, BS, * Kanwal Matharu, MD, Tanu Garg, MD, Wendy C. Tsai, MD, Purvesh Patel, MD, Jill E. Weatherhead, MD, MS, and Joseph S. Kass, MD, JD

Neurol Neuroimmunol Neuroinflamm 2019;6:e537. doi:10.1212/NXI.0000000000000537
Correspondence

Dr. Kass

kass@bcm.edu

\section{Case presentation}

A 50-year-old woman with a recent diagnosis of poorly differentiated nonteratomatous cervicouterine cancer presented to our hospital for breath-holding episodes resulting in perioral cyanosis. Her medical history was significant for chickenpox at age 8 and shingles at age 15 . Before her admission and 10 days after her cancer diagnosis, she was admitted to an outside hospital for confusion and intermittent catatonia. Workup at the outside hospital was unremarkable, and she was diagnosed with adjustment disorder. At home, she continued to decompensate and ultimately became incomprehensible, anorexic, and bedbound, prompting admission to our hospital.

On presentation, the patient was encephalopathic and dysautonomic. She was unresponsive to pain and exhibited diffuse hyperreflexia, episodes of generalized body tremors, and trismus to the point of transecting her tongue. Because of breath-holding spells with oxygen desaturations and the need to acquire a brain MRI, she was intubated. Her continuous EEG and brain MRI were unremarkable. Acyclovir was empirically started for 2 days but discontinued after CSF studies revealed lymphocytic pleocytosis ( 17 white blood cells/ $\mu \mathrm{L}$ with $86 \%$ lymphocytes) with negative herpes simplex virus (HSV) PCR (figure). A 5-day course of intravenous methylprednisolone (IVMP) and intravenous immunoglobulin (IVIG) for presumed anti-N-methyl-D-aspartate receptor encephalitis (NMDAR) encephalitis was administered. CSF testing for varicella zoster virus (VZV) by PCR returned positive, prompting a 21-day course of IV acyclovir. The NMDAR antibody CSF titer later also returned positive (1:50; Dalmau Laboratory, University of Pennsylvania, Philadelphia, PA). A diagnosis of anti-NMDAR encephalitis with concomitant VZV detection was made. A week into antiviral treatment, the patient's vital signs normalized and agitation decreased. By discharge, the patient was alert, oriented, and following simple commands but not yet at neurologic baseline.

\section{Discussion}

This case report demonstrates a rare presentation of anti-NMDAR encephalitis with concomitant VZV detection in the setting of a nonteratomatous gynecologic tumor. ${ }^{1,2}$ In a seminal case series published in 2008, about $60 \%$ of patients with anti-NMDAR encephalitis had a tumor, most often an ovarian teratoma. ${ }^{3}$ Anti-NMDAR encephalitis has also been linked with tumors of endocervical and endometrial origin. ${ }^{4}$ These tumors express NMDA receptor 1 (NR1), as well as synaptophysin, neuron-specific enolase, CD56, and chromogranin. Resection of tumors that express NRs can shorten recovery time. ${ }^{5}$ Our patient's tumor expressed synaptophysin, but NR1 testing was not performed. Thus, it is unknown whether her cervicouterine tumor demonstrates a true association with NMDAR immunoreactivity.

*These authors contributed equally to this work.

From the Department of Internal Medicine (P.A.P., K.M.), Department of Neurology (J.J., T.G., J.S.K.), Department of Anesthesia (W.C.T.), and Department of Pulmonary, Critical Care, and Sleep Medicine (P.P.), Baylor College of Medicine; and National School of Tropical Medicine (J.E.W.), Baylor College of Medicine, Houston, TX.

Funding information and disclosures are provided at the end of the article. Full disclosure form information provided by the authors is available with the full text of this article at Neurology.org/NN.

The Article Processing Charge was funded by the authors.

This is an open access article distributed under the terms of the Creative Commons Attribution-NonCommercial-NoDerivatives License 4.0 (CC BY-NC-ND), which permits downloading and sharing the work provided it is properly cited. The work cannot be changed in any way or used commercially without permission from the journal. 
Figure Time course of the patient's diagnostics and treatment

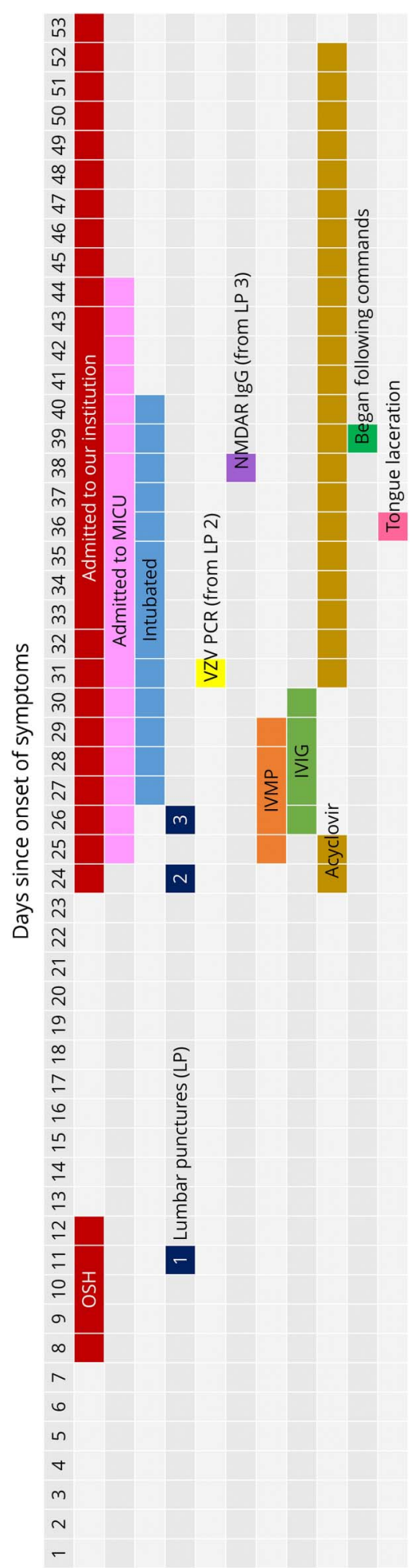

The patient initially presented to an outside hospital for altered behavior and was discharged home with a psychiatric diagnosis. When she continued to deteriorate, she presented to our hospital with breath-holding spells, encephalopathy, and dysautonomia. The patient completed a 5-day course of IVMP and IVIG for presumed anti-NMDAR encephalitis. She was initially started on broad-spectrum antibiotics and acyclovir, which were discontinued after a negative HSV PCR. Once her CSF returned positive for VZV, she was started on a 21-day course of acyclovir. HSV = herpes simplex virus; IVIG = intravenous immunoglobulin; IVMP = intravenous methylprednisolone; LP = lumbar puncture; VZV = varicella zoster virus.
Neurotropic viruses, most frequently HSV, have been linked to anti-NMDAR encephalitis. ${ }^{6}$ One proposed mechanism for this association is that these viruses may lyse neurons, releasing antigens that sensitize IgG antibodies to the NR and triggering autoimmune encephalitis. ${ }^{1,2}$ Another hypothesis is that CNS inflammation from anti-NMDAR encephalitis may cause shedding of latent viral DNA or a viral reactivation leading to secondary encephalitis. ${ }^{7}$

To date, VZV has been documented twice in the setting of antiNMDAR encephalitis. ${ }^{1,2}$ One patient presented with cranial nerve palsies and improved significantly after treatment with IV acyclovir and immunoadsorption. The other patient had a teratoma and presented with confusion and behavioral changes after a viral-like illness. She was refractory to treatment with teratoma resection, acyclovir, IVIG, and plasma exchange.

Our patient completed the full first-line therapy for both antiNMDAR and VZV encephalitis. Although her improvement in symptoms correlated temporally with antiviral therapy, the effects of the IVMP and IVIG treatment cannot be discounted because the response to immunotherapy often lags behind its completion. Because she was treated for both disease processes, it is unclear whether VZV triggered our patient's autoimmune condition or was present in the CSF as a result of latent viral shedding. Her presenting symptoms were more consistent with anti-NMDAR encephalitis than VZV encephalitis. Nevertheless, we recommend antiviral treatment in cases of antiNMDAR encephalitis with concomitant VZV detection because the immunosuppressive regimen for anti-NMDAR encephalitis may worsen an underlying VZV infection.

Previous literature suggests that anti-NMDAR encephalitis should be considered in any person aged 50 years or younger who presents with acute psychotic changes of less than 4 weeks' duration, especially in the setting of a viral prodrome or abnormal movements. ${ }^{5}$ Current standard of care for patients with suspected anti-NMDAR encephalitis is to treat with acyclovir until HSV PCR testing is complete. Our case is part of a growing body of evidence that suggests providers should continue antiviral treatment until VZV PCR testing has resulted negative as well. Additional research could investigate the optimum treatment course and prognosis when anti-NMDAR encephalitis presents with concomitant viral detection.

\section{Acknowledgment}

The authors thank Dr. Jennifer Chu for her invaluable help in interpreting the patient's EEG studies.

\section{Study funding}

No targeted funding reported.

\section{Disclosure}

P.A. Prakash and J. Jin report no disclosures. K. Matharu owns stock in Johnson and Johnson. T. Garg, W.C. Tsai, P. Patel, and J.E. Weatherhead report no disclosures. J.S. Kass received travel funding and/or speaker honoraria from the National 
Board of Medical Examiners, American Academy of Neurology, BrainPac; is an associate editor for Continuum and Continuum Audio; received publishing royalties from Elsevier; and has been a paid speaker for Pri-Med. Full disclosure form information provided by the authors is available with the full text of this article at Neurology.org/NN.

\section{Publication history}

Received by Neurology: Neuroimmunology \& Neuroinflammation September 26, 2018. Accepted in final form November 30, 2018.

\section{References}

1. Schäbitz WR, Rogalewski A, Hagemeister C, Bien CG. VZV brainstem encephalitis triggers NMDA receptor immunoreaction. Neurology 2014;83:2309-2311.
2. Solís N, Salazar L, Hasbun R. Anti-NMDA Receptor antibody encephalitis with concomitant detection of Varicella zoster virus. J Clin Virol 2016;83: 26-28.

3. Dalmau J, Gleichman AJ, Hughes EG, et al. Anti-NMDA-receptor encephalitis: case series and analysis of the effects of antibodies. Lancet Neurol 2008;7: 1091-1098.

4. Hara M, Morita A, Kamei S, et al. Anti-N-methyl-D-aspartate receptor encephalitis associated with carcinosarcoma with neuroendocrine differentiation of the uterus. J Neurol 2011;258:1351-1353.

5. Dalmau J, Lancaster E, Martinez-Hernandez E, Rosenfeld MR, Balice-Gordon R. Clinical experience and laboratory investigations in patients with NMDAR encephalitis. Lancet Neurol 2011;10:63-74.

6. Nosadini M, Mohammad SS, Corazza F, et al. Herpes simplex virus-induced anti-Nmethyl-d-aspartate receptor encephalitis: a systematic literature review with analysis of 43 cases. Dev Med Child Neurol 2017;59:796-805.

7. Linnoila J, Binnicker M, Majed M, Klein C, McKeon A. CSF herpes virus and autoantibody profiles in the evaluation of encephalitis. Neurol Neuroimmunol Neuroinflamm 2016;3:245. doi: 10.1212/NXI.0000000000000245.

Appendix 1 Author contributions

\begin{tabular}{|c|c|c|c|}
\hline Name & Location & Role & Contribution \\
\hline Preeti A. Prakash, BA & Baylor College of Medicine, Houston, TX & Author & $\begin{array}{l}\text { Conceptualized the study; conducted literature review; interpreted } \\
\text { data; and drafted and revised the manuscript for intellectual content }\end{array}$ \\
\hline Jingxiao Jin, BS & Baylor College of Medicine, Houston, TX & Author & $\begin{array}{l}\text { Conceptualized the study; conducted literature review; interpreted } \\
\text { data; created figure; and revised the manuscript for intellectual } \\
\text { content }\end{array}$ \\
\hline Kanwal Matharu, MD & Baylor College of Medicine, Houston, TX & Author & $\begin{array}{l}\text { Conceptualized the study; interpreted data; and revised the } \\
\text { manuscript for intellectual content }\end{array}$ \\
\hline Tanu Garg, MD & Baylor College of Medicine, Houston, TX & Author & $\begin{array}{l}\text { Conceptualized the study; interpreted data; and revised the } \\
\text { manuscript for intellectual content }\end{array}$ \\
\hline Wendy C. Tsai, MD & Baylor College of Medicine, Houston, TX & Author & Interpreted data and revised the manuscript for intellectual content \\
\hline Purvesh Patel, MD & Baylor College of Medicine, Houston, TX & Author & Interpreted data and revised the manuscript for intellectual content \\
\hline Jill E. Weatherhead, MD & Baylor College of Medicine, Houston, TX & Author & Interpreted data and revised the manuscript for intellectual content \\
\hline Joseph S. Kass, MD, JD & Baylor College of Medicine, Houston, TX & Author & Interpreted data and revised the manuscript for intellectual content \\
\hline
\end{tabular}




\section{Neurology \\ Neuroimmunology \& Neuroinflammation}

\section{Anti-NMDAR encephalitis with concomitant varicella zoster virus detection and nonteratomatous malignancy \\ Preeti A. Prakash, Jingxiao Jin, Kanwal Matharu, et al. \\ Neurol Neuroimmunol Neuroinflamm 2019;6; \\ DOI 10.1212/NXI.0000000000000537}

This information is current as of January 9, 2019

Updated Information \&

Services

References

Citations

Permissions \& Licensing

Reprints including high resolution figures, can be found at:

http://nn.neurology.org/content/6/2/e537.full.html

This article cites 7 articles, 0 of which you can access for free at: http://nn.neurology.org/content/6/2/e537.full.html\#\#ref-list-1

This article has been cited by 1 HighWire-hosted articles: http://nn.neurology.org/content/6/2/e537.full.html\#\#otherarticles

Information about reproducing this article in parts (figures,tables) or in its entirety can be found online at:

http://nn.neurology.org/misc/about.xhtml\#permissions

Information about ordering reprints can be found online: http://nn.neurology.org/misc/addir.xhtml\#reprintsus

Neurol Neuroimmunol Neuroinflamm is an official journal of the American Academy of Neurology.

Published since April 2014, it is an open-access, online-only, continuous publication journal. Copyright

Copyright (C) 2019 The Author(s). Published by Wolters Kluwer Health, Inc. on behalf of the American

Academy of Neurology.. All rights reserved. Online ISSN: 2332-7812.

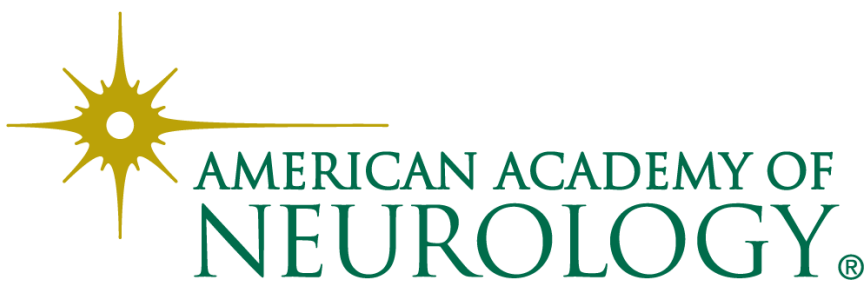

